\title{
ANALYSIS OF THE USE VALUE OF OLD HARDWARE USING OPEN SOURCE SOFTWARE
}

\author{
Dejan Viduka
}

PhD, Assistant Professor, Faculty for Applied Management, Economics and Finance, University Business Academy, Jevrejska 24/1, 11000 Belgrade, Serbia; e-mail: dejan@viduka.info

\section{Vladimir Kraguljac}

MSc, Teaching Assistant, Faculty of Hotel Management and Tourism in Vrnjačka Banja, University of Kragujevac, Vojvođanska bb, 36210 Vrnjačka Banja, Serbia; e-mail: vladimir.kraguljac@kg.ac.rs

\section{Jasmina Đurašković}

$\mathrm{PhD}$, Assistant Professor, Faculty of Project and Innovation Management, University Educons, Bože Jankovića 14, 11000 Beograd, Serbia; e-mail: jasmina.djuraskovic@pmc.edu.rs

\begin{abstract}
At the beginning of the 21st century, Information and Communication Technologies (ICT) became an essential element of all spheres of life. The great opportunities these technologies provide are insufficiently used in many developing countries and one of the reasons for this is the lack of equipment. The aim of this paper is to present new areas for researches in the field of information systems, as well as showcase the opportunities and impacts of Open Source Software. The paper compares Microsoft Windows and GNU/Linux Ubuntu operating systems, the applicability and superiority of which have long been debated in the world of information technologies. The paper determines the possibilities for the prolonged use of old hardware by using open source software. In order to prove the applicability of these systems on old hardware, we have conducted tests that indicate the possibility of using both systems on the same hardware architectures.
\end{abstract}

Key words: hardware, costs, open source software, testing, operating systems

\section{INTRODUCTION}

The information and communication technologies (ICT) are a force that has changed many aspects of modern life (Oliver, 2002; Kraguljac \& Milasinovic, 2016). The end of 20th and beginning of the 21st century marked an expansion of the use of computers in everyday life. This expansion was encouraged by a rapid technology development, which became cheaper and more available to ordinary users, both at work and at home. 


\section{Viduka, V. Kraguljac, J. Đurašković: Analysis of the Use Value of Old Hardware... Zbornik Veleučilišta u Rijeci, Vol. 9 (2021), No. 1, pp. 315-328}

Despite a drastic fall in equipment prices, for many developing countries, these prices are still high and for this reason, modern technologies are not available to many of their citizens. One of the potential solutions is the prolonged use of old hardware, which would give them an opportunity to follow modern trends. Computer systems managers make decisions about hardware - software selection, performance evaluation, capacity planning, and other resource variables based on actual data, accounting data, judgement, and assumptions about the resource consumption of the tasks being run (Zviran, 1999).

The problem is particularly pronounced with the activities that are almost exclusively financed from the budget, such as the education system, because the funds allocated for them are usually very modest. The higher education institutions are particularly affected and thus many students do not have an opportunity to acquire knowledge with the use of new technologies. The problem gets new dimensions having in mind the fact that these students should contribute to the much needed rapid development of their country as soon as they complete their education. Even countries that are able to purchase newer equipment face the similar problem, as this equipment quickly becomes outdated. Despite the strong presence of computers in everyday life and their unique role in the education system, the possibilities for their use in everyday work in schools in the Republic of Serbia are not even partially used. There are many reasons for this, starting from the lack of technical equipment in schools, through the lack of competence and motivation of teachers for this method of work, to acquiring habits for reaping benefits that the computers provide in the teaching process (Ibrahimovic, 2014).

According to the research carried out in Serbia (USAID, 2017), the biggest problems the citizens see in the functioning of educational institutions are poor condition and obsolescence of IT equipment and technology (29\%), followed by extremely broad (44\%) and old-fashioned (29\%) curricula. In 2016, a failure to meet the technical conditions postponed the adoption of a new curriculum for the fifth and sixth grade of the primary school, which defines computer science as a compulsory subject in the Serbian education system. The key technical requirements that were not met are the availability of computers and Internet in schools, software licensing, system maintenance and staff training (Lipkovski \& Radic, 2016).

2,800 classrooms are equipped with computers and Internet. However, seven percent of schools in Serbia do not have an Internet access and a total of 2,700 computers are missing (Lipkovski \& Radic, 2016). The main cause that is stated is the lack of economic resources for the purchase of equipment and the irregularities in the use of the budget for the procurement of IT equipment. Thus, the Anti-Corruption Council of the Republic of Serbia analysed the costs of public purchases of computers, spare parts, maintenance services, software and license purchases. Considering that all local self-government units have reported extremely high costs for the procurement of computer equipment, and having in mind the fact that they state that the major problem that hinders their undisturbed operation is the lack of equipment, the question that reasonably arises is whether these procurement procedures have actually been implemented in the stated amount, which consequently raises the issue of corruption (SZBPK, 2016). 
In order to achieve savings in the education system of the Republic of Serbia, one question has to be asked: Is it possible to leverage the existing IT resources, even outdated, to make (AndersenGott et al., 2012). "a shift in how commercial companies view open source software" following the role model of business users in the world?

In this regard, a moral obligation to contribute to open source is emphasized, which would use the knowledge as the main asset of educational institutions to reduce the costs of software licenses and improve the quality of the education system. In practice, open source software - OSS is often mentioned as low-cost software that could successfully replace well-known commercial software systems run by Microsoft and Apple (Viduka et al., 2017/a).

This solution is acceptable from the point of view of savings in software purchases, but the question remains about the continued use of old software in the teaching process with the acquisition of newer hardware (Viduka et al., 2017/b).

Many people see savings in the purchase price of new software, but they forget the fact that hardware is always replaced along with the new software, which increases the purchase costs for even up to $50 \%$ of the initial investment. On the other hand, the open source software advocates often point out that software is well-optimized (Borocz et al., 2018) and for this reason allows successful operation on old hardware.

The question that arises is whether it is possible to use old hardware to run new-generation software. In addition, it is also necessary to check other conditions, i.e. whether newer software is safe for computers and computer networks and the like. The old computers that are often encountered in users with a lower purchase power were used for testing.

These computers were purchased in the period from 2004 to 2014. The intention of this paper is not to determine which software systems are better, but to offer an alternative approach to the optimal use of old hardware by using modern software in education, business and everyday use.

The paper is structured as follows. The introductory part is followed by a review of Open Source Software and the motives for conducting such research. Then, the methodology behind the research and a review of previous similar research are explained. Ultimately, the obtained results are presented and discussed, conclusions are drawn and possible directions for future research are presented.

\section{1 About Open Source Software}

Today, OSS is interpreted in two different ways - as "Free Software" and "Open Source". To understand this concept, it is important to understand that the free software in question is not always free, but may or may not be depending on the author's choice. In this context, the word "free" should be used as in "free speech", not as in "free beer".

Users of such software have the right to use, modify and share it with other users. This type of software has many advantages and it is widely used. In recent years, the term "Open Source Hardware" has been frequently used in science and education. 
Users cite several important differences between GNU/Linux and Microsoft Windows, some of which are:

1. Linux is free. This is true for some variants. However, chargeable variants include customer support from the companies that develop it.

2. It is much safer, because there are very few or no viruses for Linux.

3. It is updated frequently, meaning that the errors found are corrected more quickly, which further affects stability and security.

4. It is more customizable. The user can tailor every aspect of the operating system to their needs and desires.

The file system used is ext4, unlike Windows where it is NTFS. This directly affects stability and data processing speed.

\subsection{Motive for this research}

In recent years, various professional forums and social media groups have raised the issue of using Open Source software as a replacement for Microsoft Windows solutions. The topic most often discussed is the use of old hardware that uses Microsoft software, which has ceased to provide official support, and thus has become less secure. It is often related to users not having the money to buy new hardware or software from the same company, thinking about alternative software solutions that can run on older hardware. It is usually the more experienced users that recommend trying to use OSS, especially one of the GNU/Linux distributions. Most commonly suggested are Ubuntu, Lubuntu, Edubuntu, Kubuntu, Xbuntu, etc. Such recommendations almost always finish with claims that this software can extend the usage of old hardware with little or no investment.

Our aim was to scientifically test these claims and make test results available to potential users. Our goal is to enable as many users as possible to use computers in education and at home. One way to accomplish this is to take advantage of the old hardware that users already own. Additionally, when purchasing equipment, old computers are significantly less expensive while still offering the opportunity to work and learn. This furthermore reduces the digital divide between the rich and the poor, a problem of growing prominence in contemporary society.

The authors particularly strive to reduce the digital divide as much as possible in education, where it affects young people eager for knowledge. This is certainly just one of the suggestions for achieving that. An additional benefit is the reduction of electronic waste affecting our planet.

Our motive was to find out whether the claims made by experienced users on the utilization of hardware capabilities of older hardware were correct, and not to judge which software was better and more reliable. The aim was to establish facts using scientific methods, and make them publicly available to anyone who wants to prolong the use of old hardware. We believe that by providing scientifically confirmed facts and making them publicly available to experts and laymen alike, science fulfills one of its purposes in helping the economy, and society in general, to overcome obstacles and develop as quickly as possible. 
Practical confirmation of these claims was obtained as a part of the project (By Clicking to Independence - Through Children's Village into the Virtual World) intended to enable young people (of legal age) without parental care to use computers and attempt to gain financial independence by guiding them into entrepreneurial waters. Their old classroom (Figure 1) was used as an example to prove the results of the tests obtained in our laboratory in practice. The hardware used by the aforementioned users was mainly obtained as a donation from companies that no longer had use for it. By installing OSS, we prolonged its usage. One of the biggest complaints of users (the students) about GNU/Linux installation was that very few games could be played on these computers. The teachers, on the other hand, found this advantageous as their primary purpose was for the students to use the computers for learning and working instead of playing games. Our experience with this test environment was identical to the following scientific tests.

Figure 1. The classroom we used for testing

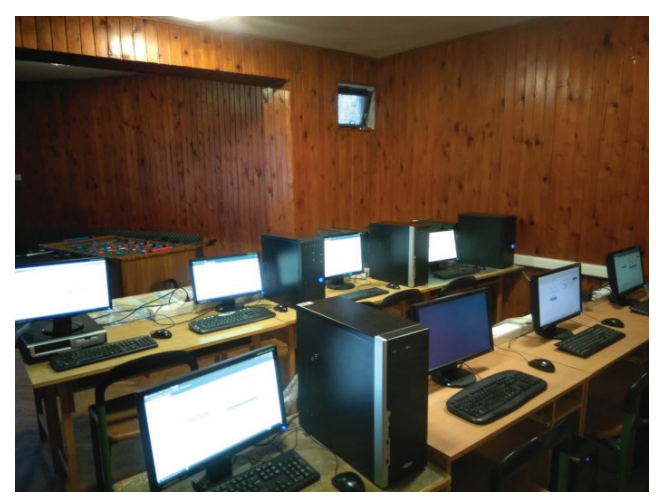

\section{METHODOLOGY}

"GeekBench 2.4.3 Tryout (32-bit)" benchmark software (OTS, 2014) was used to measure hardware performance on two different eco-systems, i.e. operating systems. The first system was Microsoft Windows in three versions. The second system was GNU/Linux Ubuntu in two versions.

This software was chosen based on personal experience, recommendations of Internet users and because it is one of rare software that can be used on both operating systems (Microsoft Windows - MS and GNU/Linux) and in all test configurations.

The five computers configurations were selected for testing purposes and the following versions (32bit) were installed on them (Viduka, 2017):

- MS Windows XP Professional,

- Ubuntu Linux 12.04.1 LTS,

- MS Windows 7,

- Ubuntu Linux 14.04 LTS, and

- MS Windows 8 Pro. 
The Ubuntu distribution of GNU / Linux was chosen because of its high popularity among users, as well as due to its visual and functional similarity with Microsoft software solutions to which users are already accustomed, which allows a relatively easy switch.

The testing results were compared, and based on these results, a discussion was conducted on the possibilities of using tested operating systems, older and newer, as well as software that comes with them.

\section{PREVIOUS RESEARCHES}

Open Source is a type of software that can essentially affect the business and economic characteristics of the software industry. In the last 10 to 15 years there have been a lot of researches on the application of Open Source Software (OSS) in business and education. An upward trend in the use of OSS in higher education in many countries of the world is evident (Van Rooij, 2007).

This topic is very popular in professional circles, but almost always the goal is to analyse the cost of procurement, as well as possible savings due to the application of OSS or switch to OSS. Even this research has a similar aim, but here savings are achieved through the use of an old, already existing, hardware. It is possible to view the topic from several angles - through economic, hardware and pedagogical factors, software can be seen as a craft of the future, its sociological, cultural, legal aspects, etc. can be measured. (Bonaccorsi \& Rossi, 2003; Djordjevic et al., 2004; Singh \& Seehan, 2012).

\section{TESTING RESULTS}

As noted above, the five computer configurations (laptops) with completely new operating systems and testing software were tested and the results shown in Tables were obtained. The computers that were tested and their hardware architecture are as follows:

A) LG Electronics GS50-6FH1 (2004)

- Processor: Intel Celeron M 1.40GHz @ $1.40 \mathrm{GHz}$ (1 processor)

- Processor ID: Genuinelntel Family 6 Model 13 Stepping 8

- Memory: 1024 MB DDR SDRAM $167 \mathrm{MHz}$

B) Acer Aspire 3690 (2006)

- Processor: Intel Celeron M 420 @ $1.60 \mathrm{GHz}$ (1 processor)

- Processor ID: Genuinelntel Family 6 Model 14 Stepping 8

- Memory: 1024 MB DDR2 SDRAM $267 \mathrm{MHz}$

C) Hewlett-Packard Presario CQ61 Notebook PC (2009)

- Processor: AMD Turion II Mobile M500@2.20 GHz (1 processor, 2 cores)

- Processor ID: AuthenticAMD Family 16 Model 6 Stepping 2

- Memory: $3021 \mathrm{MB}$ 
D) Acer Aspire $7739 \mathrm{Z}(2011)$

- Processor: Intel Pentium P6200 @ $2.13 \mathrm{GHz}$ (1 processor, 2 cores)

- Processor ID: Genuinelntel Family 6 Model 37 Stepping 5

- Memory: 3699 MB (4096 MB DDR3 SDRAM $534 \mathrm{MHz})$

E) Hewlett-Packard HP EliteBook 840 G1 (2014)

- Processor: Intel Core i5-4200U @ $2.30 \mathrm{GHz}$ (1 processor, 2 cores, 4 threads)

- Processor ID: Genuinelntel Family 6 Model 69 Stepping 1

- Memory: $2892 \mathrm{MB}-1 \mathrm{MHz}$.

Most computers used in the education system use MS Windows XP, for which Microsoft announced a support cessation in 2014, (Viduka \& Basic, 2015) and the possession of this operating system also endangers the computers and networks that form a part of these computers. It is virtually impossible to install newer programs on such an old operating system, so there is also this restriction.

The testing results are shown below. The first computer is the computer purchased for technical purposes in 2004. (A1, A2, A3, A4 \& A5, 2014) It has very outdated hardware architecture, but it can still be found in practice, especially in education. The results in Chart 1 show that the best results are achieved using the older version of GNU / Linux Ubuntu 12.04 LTS.

Chart 1. Testing results of Computer $A$

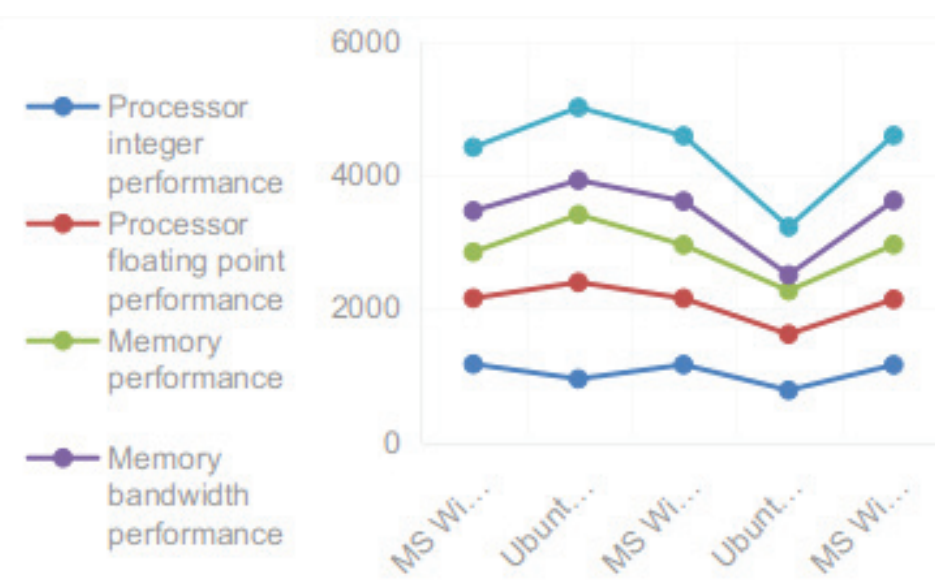

Below are the test results of the computer purchased in 2006. (B1, B2, B3, B4 \& B5, 2014) Chart 2 shows that in this case the best results were achieved using the older version of the GNU / Linux Ubuntu 12.04 LTS operating system.

Chart 2. Testing results of Computer B 


\section{0}
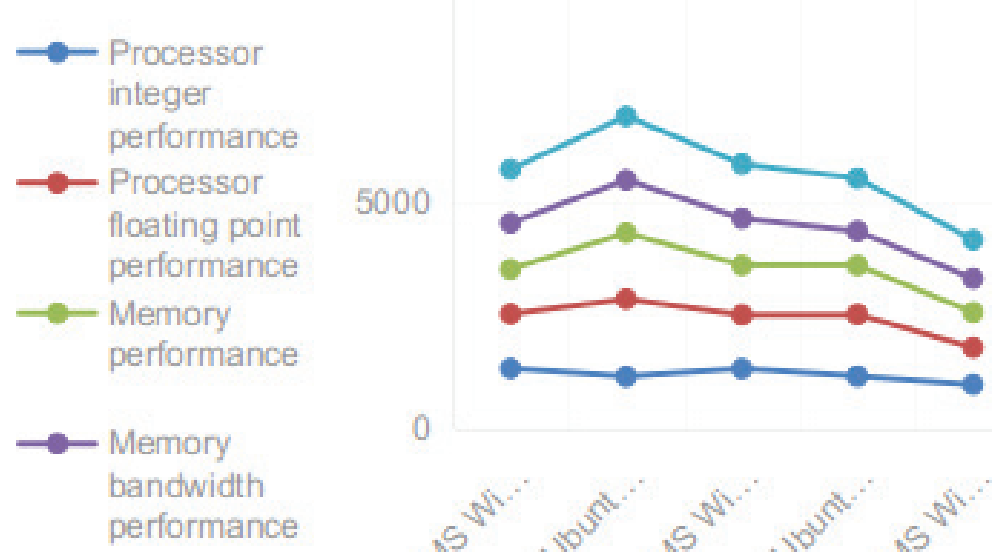

0

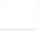

During the testing of the computer purchased in 2009 (C1, C2, C3 \& C4, 2014), there was a problem in the installation of the MS Windows XP operating system and for this reason this column is empty. Chart 3 shows an absolute dominance of both GNU/Linux Ubuntu operating systems.

\section{Chart 3. Testing results of Computer $\mathrm{C}$}

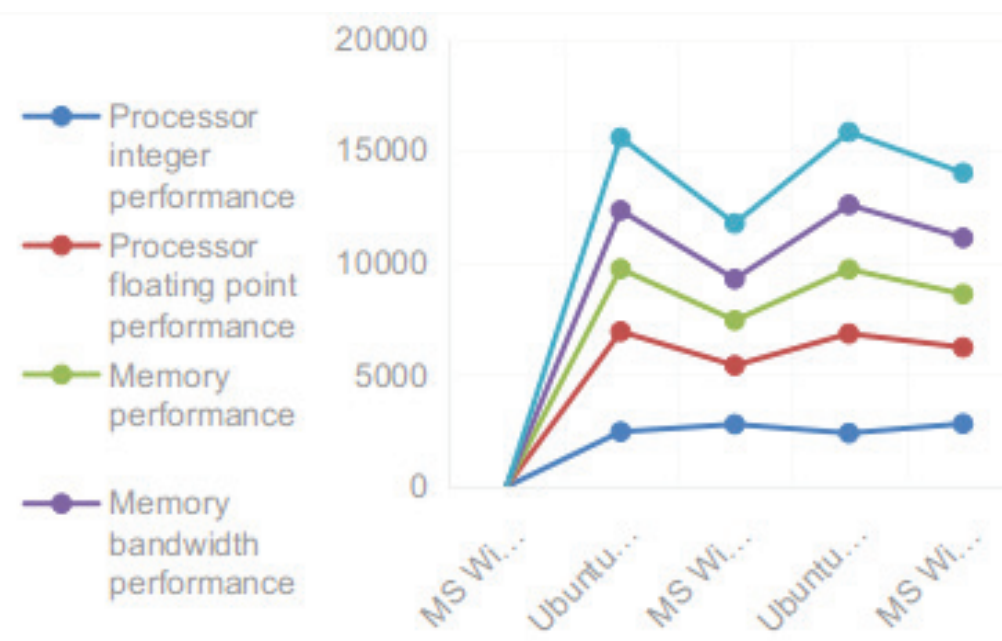

The problem with the installation of the MS Windows XP reoccurred on the fourth computer. Chart 4 (D1, D2, D3 \& D4, 2014) shows the dominance of GNU / Linux Ubuntu operating systems.

The differences in results can be seen only by looking at the numbers, however, this difference is even more pronounced in the work itself.

Chart 4. Testing results of Computer D 


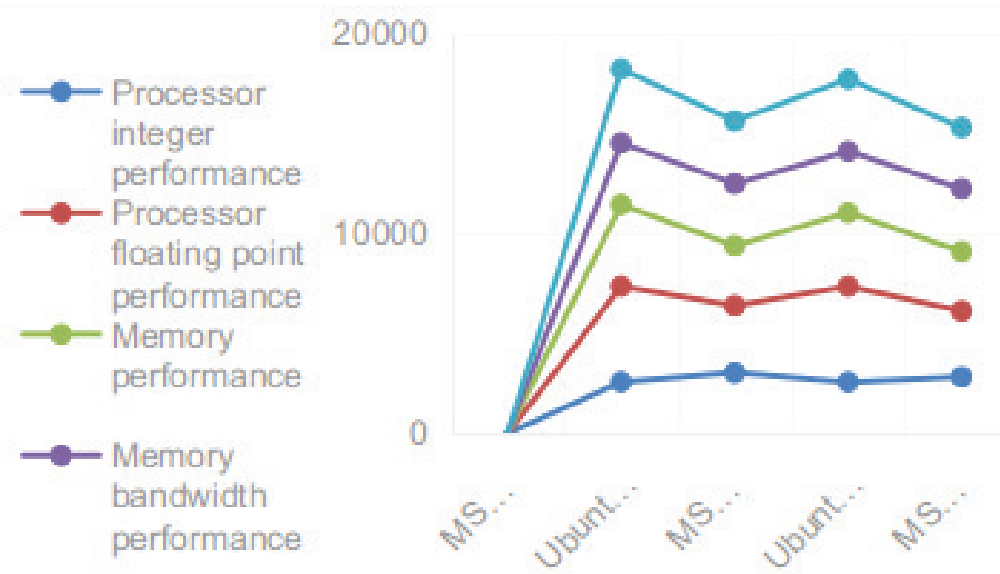

The last in a series of tested computers is the latest computer, which is often used today and which was purchased in 2014. (E1, E2, E3 \& E4) Chart 5 also shows the dominance of GNU/Linux Ubuntu 14.04 LTS operating system.

Chart 5. Testing results of Computer $\mathrm{E}$

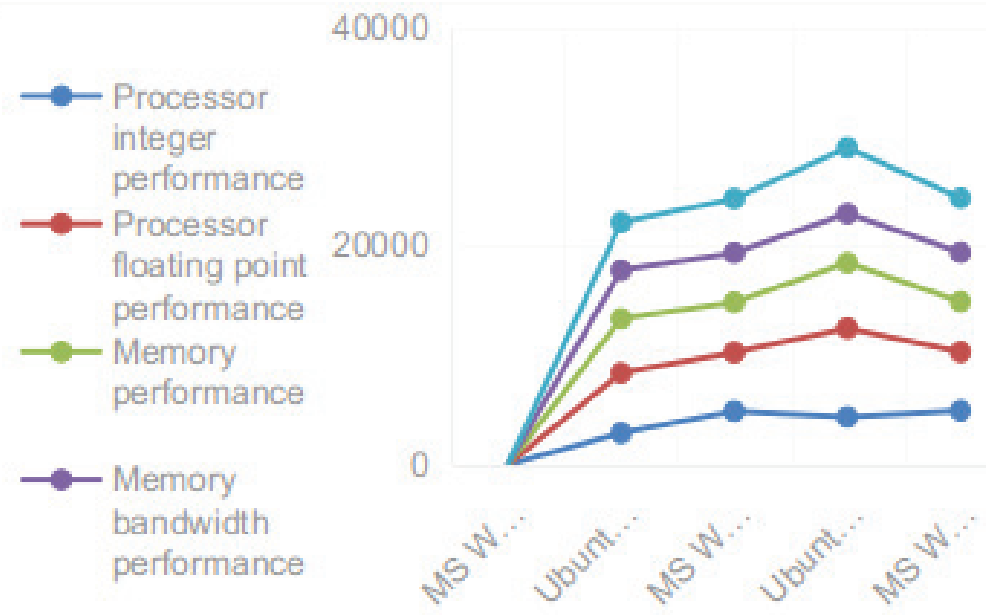

The tables summarize the results of the tests that have been conducted. The links to the detailed results are available in the references at the end of the paper.

\section{DISCUSSION OF TEST RESULTS}

The computer technology market is large and rapidly evolving, and entails the development of necessary software, especially the operating systems, which have prominently developed in the last 
few decades. But it still leaves an open question about the length of use of a specific computer can be used and with which software solutions.

The fight for market dominance will never stop, contributing to the creation of more stable, better and cheaper operating systems that can cope with the growing needs of users. The MS Windows and Linux singled out in this battle for the market of operating systems.

The users of these two systems often have discussions on which operating system is better and more usable. Microsoft took a large share of the market with Microsoft Windows, so we tried to compare this system with Linux and get an answer, which operating system is more applicable in the modern business, education or any other activity performed with the assistance of computers.

Some EU countries and their administrations are in the process of deciding to switch to OSS. This leads us to a conclusion that the demand for this profile of experts will grow. The users who have already used this software during their education, professional practice or privately, will have an advantage. It will be easier for them to upgrade the knowledge needed for the job. The opportunities for broader use of OSS that are noted here and the fact that it covers a wide range of services in various areas, especially in the Internet business, create opportunities for a higher percentage of youth employment, as well as development of entrepreneurship.

It can be clearly seen that GNU / Linux Ubuntu has shown better performance than MS Windows in all tests. The test results confirm the opinion that it has much better use of computer resources. We conclude that it is also possible to use older computers with the GNU / Linux operating system. The users often similarly rate other OSSs.

Although there have been claims that the GNU/Linux operating system has a problem with functioning on some types of hardware over the past years, this did not happen during this testing. A minor exception is the oldest computer that needed an external keyboard for the installation of the latest version of Ubuntu Linux.

At first glance, it seems that the difference in the results achieved is not convincingly beneficial for OSS. Therefore, it is important to note that there were no other application programs on computers with MS Windows versions, in addition to the operating system and testing programs. On the other hand, as a rule, the GNU / Linux Ubuntu comes with a number of applications installed that give users a wide range of opportunities for smooth operation, but also negatively affect the performance of the computer itself.

The tests have shown that the GNU/Linux (Ubuntu) operating system can be successfully used on the same computers as Microsoft Windows. This is important information especially for users who have older hardware, which is delivered and designed for use with the older Microsoft operating system.

Chart 6 shows the results summarized by the test software, which clearly indicate that GNU/Linux better uses the available hardware resources. The older computers were dominated by older Linux 12.04 LTS, but not with a big difference, while a newer version of Ubuntu GNU/Linux-a 14.04 LTS has a compelling advantage on newer computers. 
Chart 6. Summary of Geekbench test

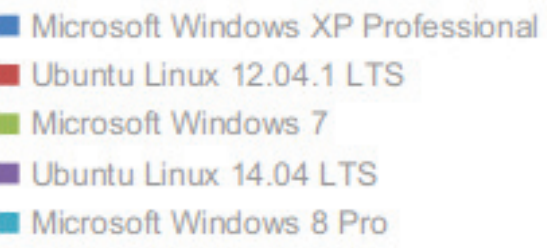

8000

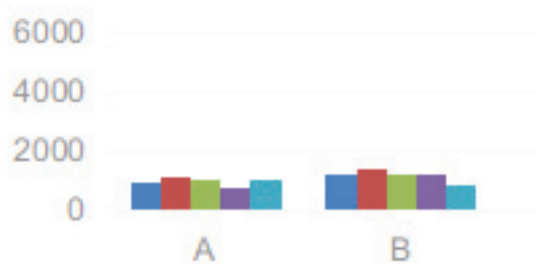

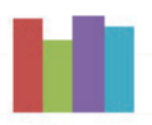

C

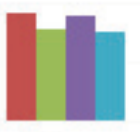

D

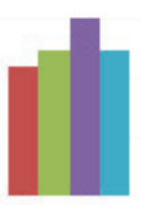

E

The plan for future research is to do more extensive tests, but only on the last two versions of the operating systems Windows and Linux Ubuntu.

\section{CONCLUSION}

Education and application of ICT, from the point of modern understanding of this phenomenon, are some of the basic postulates of the national interest of each country. The paper shows how the OSS project (GNU / Linux) can affect the development and improvement of education, but also other areas, and the benefits can be achieved in relation to the well-known commercial software packages. For many users this high-level view sounds nice, but the question that arises here is why most companies and individuals do not use open source software? One of the reasons is that only few years ago the open source operating systems (mainly GNU / Linux distribution) started to support enough hardware, deliver sufficiently usable applications and be at that level that does not to require advanced IT knowledge to be used by end users. The aim of the proposed model is to present another idea for research in the field of information systems, which has a different approach to the use of available hardware resources.

This paper tried to examine the connection and impact of software, primarily the operating systems, on the usability and price of the widely used hardware. Based on the tests that were carried out, it is clear that the OSS operates much better on older hardware compared to more common commercial software. The similar results were obtained for newer hardware. This claim affects the possibility of using old hardware that is currently available in many institutions, companies and homes, but also on the purchase price of new hardware and the fact that new hardware also requires new software that increases costs.

As this paper particularly focuses on education, we can conclude that this model has a good chance of success and can enable schools to continue teaching with old equipment. The use of 
computers and equipment older than 10 years, can mean more hardware available for various tests and calculations, not just for standard work on desktop computers.

The old question about which of these two operating systems is better slowly loses its ambiguity. It is certain that the Linux is increasingly becoming a good alternative to Windows, even in areas where it has been long dominant. The strengthening of the Open Source concept enables Linux to accelerate its development, improve and adapt to users, making it more competitive and more reliable.

It is important to remember that although Linux is a free operating system, the investment costs themselves will not be decreased to a great extent, but a much more flexible, reliable and secure system will be obtained. All of the above leads us to a conclusion that Open Source Software can compete with commercial software in many segments.

\section{REFERENCES}

Američka agencija za međunarodni razvoj (USAID), Evropski pokret u Srbiji i Centar za evropske politike. (2017). Stavovi građana o zadovoljstvu uslugama predškolskog i osnovnog obrazovanja u Srbiji: Sažetak rezultata istraživanja. http://www.mojauprava.rs/wp-content/uploads/2017/11/USAID-Skolstvo-analiza-rezultata.pdf, (7.7.2018).

Andersen-Gott, M., Ghinea, G., Bygstad, B. (2012) Why do commercial companies contribute to open source software?. International Journal of Information Management, 32(2), 106-117.

Borocz, P., Tar, P., Maros, I. (2018) Comparison of Vector Operations of Open-Source Linear Optimization Kernels. Acta Polytechnica Hungarica, 15(1).

Bonaccorsi, A., Rossi, C. (2003) Why Open Source software can succeed. Elsevier Science B.V.

Djordjevic, B., Pleskonjic, D., Macek, N. (2004) Operativni sistemi: UNIX i Linux. Viša elektrotehnička škola Beograd.

Ibrahimovic, S. (2014) Obrazovna tehnologija i savremena nastava. http://journal.ftn.kg.ac.rs/download/SIR/SIR\%20 Samer\%20lbrahimovic\%20851_2012.pdf, (7.7.2018).

Kraguljac, V., Milasinovic, D. (2016) Some practical aspects of business informatics education in hotel management and tourism. D. Cvijanović et al, eds: Tourism in function of development of the Republic of Serbia, University of Kragujevac, Faculty of Hotel Management and Tourism in Vrnjačka Banja, 501-517, ISBN 978-86-89949-11-7, http:// www.hit-vb.kg.ac.rs/conference/images/thematic_proceedings/thematic-proceedings-ii.pdf.

Lipkovski, A., Radic, B. (2016, April 20) Informatika obavezan predmet, a mnoge škole još nemaju računare i Internet. https://www.blic.rs/vesti/drustvo/informatika-obavezan-predmet-a-mnoge-skole-jos-nemaju-racunare-i-internet/ xks83jy.

Oliver R. (2002) The role of ICT in higher education for the 21st century: ICT as a change agent for education. HE21 Conference.

Online test softver - OTS (2014) http://www.primatelabs.com.

Savet za borbu protiv korupcije - SZBPK (2016) Izveštaj o svrsishodnosti trošenja budžetskih sredstava jedinica lokalne samouprave. http://www.antikorupcija-savet.gov.rs/izvestaji/cid1028-3231/izvestaj-o-svrsishodnosti-trosenjabudzetskih-sredstava-jedinica-lokalne-samouprave. (7.7.2018).

Singh, H., Seehan, D. (2012) Open Source vs. Proprietary Solutions: Case Study of Windows and Linux, A Consumer Perspective. International Journal of Advanced Technology \& Engineering Research (IJATER).

Van Rooij, S.W. (2007) Open Source software in US higher education: Reality or illusion?. Educ Inf Technol, Springer Science + Business Media, LLC, 12, 191-209. 
Viduka, D., Basic, A. (2015) Impact of Open Source software on the environmental protection. Computational Ecology and Software, 5(1), 113-11.

Viduka, D., Basic, A., Kraguljac, V. (2017a) Social Engineering of Open Source Software. Serbian Journal of Engineering Management, Belgrade, 3 (1).

Viduka, D., Basic, A., Viduka, B. Varadjanin, V., (2017b) Open Source software as Alliterative and Effective Learning Environments. Journal SYLWAN, 161 (6).

Viduka, D. (2017) Model interoperabilnosti informacionog sistema zasnovanog na open source softveru u obrazovanju (Doctoral dissertation). Univerzitet Singidunum, Beograd.

Zviran, M. (1999) Select: A Decision Support System for Computer Family Selection. Journal of Computer Information Systems, 39 (2), 101-112.

\section{APPENDIX}

Online A1-test resultati (2014): http://browser.primatelabs.com/geekbench2/2476062

Online A2-test resultati (2014): http://browser.primatelabs.com/geekbench2/2476091

Online A3-test resultati (2014): http://browser.primatelabs.com/geekbench2/2477565

Online A4-test resultati (2014): http://browser.primatelabs.com/geekbench2/2507047

Online A5-test resultati (2014): http://browser.primatelabs.com/geekbench2/2479924

Online B1-test resultati (2014): http://browser.primatelabs.com/geekbench2/2474860

Online B2-test resultati (2014): http://browser.primatelabs.com/geekbench2/2475398

Online B3-test resultati (2014): http://browser.primatelabs.com/geekbench2/2474868

Online B4-test resultati (2014): http://browser.primatelabs.com/geekbench2/2474947

Online B5-test resultati (2014): http://browser.primatelabs.com/geekbench2/2479946

Online C1-test resultati (2014): http://browser.primatelabs.com/geekbench2/2476367

Online C2-test resultati (2014): http://browser.primatelabs.com/geekbench2/2476318

Online C3-test resultati (2014): http://browser.primatelabs.com/geekbench2/2476581

Online C4-test resultati (2014): http://browser.primatelabs.com/geekbench2/2479867

Online D1-test resultati (2014): http://browser.primatelabs.com/geekbench2/2481531

Online D2-test resultati (2014): http://browser.primatelabs.com/geekbench2/2481554

Online D3-test resultati (2014): http://browser.primatelabs.com/geekbench2/2477315

Online D4-test resultati (2014): http://browser.primatelabs.com/geekbench2/2481564

Online E1-test resultati (2014): http://browser.primatelabs.com/geekbench2/2497201

Online E2-test resultati (2014): http://browser.primatelabs.com/geekbench2/2496936

Online E3-test resultati (2014): http://browser.primatelabs.com/geekbench2/2497225

Online E4-test resultati (2014): http://browser.primatelabs.com/geekbench2/2496956 


\title{
ANALIZA UPORABNE VRIJEDNOSTI ZASTARJELOG SKLOPOVLJA KORIŠTENJEM SOFTVERA OTVORENOG KODA
}

\author{
Dejan Viduka
}

Dr. sc., docent, Fakultet za primijenjeni menadžment, ekonomiju i financije, Sveučilišna poslovna akademija, Jevrejska 24/1, 11000 Beograd, Srbija; e-mail: dejan@viduka.info

\section{Vladimir Kraguljac}

Mr. sc., asistent, Fakultet za hotelijerstvo i turizam u Vrnjačkoj Banji, Sveučilište u Kragujevcu, Vojvođanska bb, 36210 Vrnjačka Banja, Srbija; e-mail: vladimir.kraguljac@kg.ac.rs

\section{Jasmina Đurašković}

Dr. sc., docentica, Fakultet za projektni i inovacijskni menadžment, Univerzitet Educons, Bože Jankovića 14, 11000 Beograd, Srbija; e-mail: jasmina.djuraskovic@pmc.edu.rs

\section{SAŽETAK}

Početkom 21. stoljeća informacijske i komunikacijske tehnologije (IKT) postale su ključni element u svim sferama života. Široki raspon mogućnosti koje ove tehnologije pružaju nedovoljno se koriste u mnogim zemljama u razvoju, a jedan je od razloga za to nedostatak opreme. Cilj je ovoga rada predstaviti nova područja za istraživanje u području informacijskih sustava, kao i prikazati mogućnosti i utjecaje softvera otvorenog koda. Rad uspoređuje operativne sustave Microsoft Windows i GNU/Linux Ubuntu, o čijoj se primjenjivosti i superiornosti dugo raspravlja u svijetu informacijskih tehnologija. Rad određuje mogućnosti za produljeno korištenje zastarjelog sklopovlja uporabom softvera otvorenog koda. Kako bi se dokazala primjenjivost ovih sustava na zastarjelom sklopovlju, provedeni su testovi koji upućuju na mogućnost korištenja oba sustava na istim arhitekturama sklopovlja.

Ključne riječi: sklopoulje, troškovi, softver otvorenog koda, testiranje, operativni sustavi 